\title{
Correlation of the activation of the fourth component of complement (C4) with disease activity in systemic lupus erythematosus
}

\author{
G SENALDI, V A MAKINDE, D VERGANI, AND D A ISENBERG
}

From the Department of Immunology, King's College School of Medicine and Dentistry, London; and the Bloomsbury Rheumatology Unit, Rheumatology Research Department, University College and Middlesex Hospital and Medical School, London

SUMMARY Levels of C4d, a fragment of $\mathrm{C} 4$ generated during activation of the classical complement pathway, were measured in the plasma of 48 patients with systemic lupus erythematosus, 11 with inactive (group 1), 23 with mildly active (group 2), 14 with moderately/severely active disease (group 3), and 30 healthy subjects. Levels of $\mathrm{C} 3 \mathrm{~d}, \mathrm{C} 4$, and $\mathrm{C} 3$ were also measured and the $\mathrm{C} 4 \mathrm{~d} / \mathrm{C} 4$ and $\mathrm{C} 3 \mathrm{~d} / \mathrm{C} 3$ ratios calculated. C4d levels correlated with the degree of disease activity, being higher in group 3 than in group 2, in group 2 than in group 1, and in group 1 than in controls. $\mathrm{C} 4 \mathrm{~d} / \mathrm{C} 4$ gave a similar result. Activation indices of the common complement pathway, $\mathrm{C} 3 \mathrm{~d}$ and $\mathrm{C} 3 \mathrm{~d} / \mathrm{C} 3$, also correlated with disease activity, but in a non-linear relationship, failing to discriminate between patient groups. $\mathrm{C} 4$ and $\mathrm{C} 3$ showed no correlation with disease activity. These results indicate that indices of $\mathrm{C} 4$ activation, $\mathrm{C} 4 \mathrm{~d}$ and $\mathrm{C} 4 \mathrm{~d} / \mathrm{C} 4$, provide a laboratory measure of disease activity in lupus patients, for whom an objective assessment of the severity of the disease is not readily available.

Systemic lupus erythematosus (SLE) is an autoimmune disease characterised by a wide variety of clinical manifestations and serological abnormalities. ${ }^{1}$ Such diversity has greatly complicated the practical problem of developing tests which can provide a useful guide to disease activity. ${ }^{2}$

Attempts have been made to correlate the clinical condition of lupus patients with various laboratory measures, including major markers of inflammation like the erythrocyte sedimentation rate and $C$ reactive protein. Their reliability, however, still remains uncertain. ${ }^{34}$

Autoantibodies, immune complexes, and complement, which are directly involved in the pathogenesis of the disease, have been studied extensively. ${ }^{56}$ The value of measuring anti-double stranded DNA antibodies to assess disease activity is controversial: in some studies a good correlation has been found between titres of anti-double stranded DNA antibodies and disease severity, ${ }^{78}$ especially in patients with renal involvement ${ }^{9}$; such a correla-

Accepted for publication 21 April 1988.

Correspondence to Dr D Vergani, Department of Immunology, King's College School of Medicine and Dentistry, Denmark Hill, London SE5 8RX. tion was less marked in other studies, however. ${ }^{10} 11$ Levels of circulating immune complexes have also been reported to reflect disease activity in SLE, ${ }^{12}$ but several authors have failed to confirm the clinical usefulness of this parameter. ${ }^{41314}$

Involvement of the complement system in SLE has been unequivocally demonstrated by turnover studies. Radiolabelled C3 administered to lupus patients is hypercatabolised and the degree of catabolism is related to disease phase. ${ }^{15}$ This invasive method, however, is not suitable for clinical application. Complement activation in SLE has usually been assessed by the reduction, due to consumption, in the levels of intact complement components. ${ }^{16}$ This may be misleading, as an increase in the synthesis of these proteins might compensate their accelerated catabolism, maintaining their levels within normal range. ${ }^{17}$ Furthermore, in SLE low levels of complement factors could be genetically determined, as has been described for $\mathrm{C} 4 .^{18}$

Complement activation is incontrovertibly documented by detection of complement fragments. ${ }^{19}$ Fragment C3d has been found to be increased in lupus patients, but its level did not correlate with the degree of disease activity. ${ }^{20}$ As tissue damage in 
SLE is caused by immune complexes, ${ }^{5}$ which trigger the complement cascade through the classical pathway, ${ }^{21}$ we decided to measure the classical pathway fragment $C 4 \mathrm{~d}^{22}$ in lupus patients with different degrees of disease activity using a newly developed technique. ${ }^{23}$ We also measured levels of $\mathrm{C} 3 \mathrm{~d}, \mathrm{C} 4$, $\mathrm{C} 3$, and calculated the $\mathrm{C} 4 \mathrm{~d} / \mathrm{C} 4$ and $\mathrm{C} 3 \mathrm{~d} / \mathrm{C} 3$ ratios to obtain indices of complement activation independent of the concentration of the parent molecules.

\section{Subjects and methods}

S U B J E C TS

Forty eight consecutive patients with SLE (45 female; mean age 40 years, range 21-67) attending an established outpatient lupus clinic at the Bloomsbury department of rheumatology of University College and the Middlesex Hospital, London, were studied. All the patients met at least four of the American Rheumatism Association's revised criteria for the classification of the disease. ${ }^{24}$ The disease was judged to be inactive in 11 (disease activity grade 1), mildly active in 23 (grade 2 ), and moderately/severely active in 14 patients (grade 3), according to previously reported criteria. ${ }^{20}$ Each patient was clinically assessed by a single examiner (DAI) at the time of blood collection.

Thirty healthy individuals (18 female, mean age 32 years, range 27-47) from the laboratory personnel at King's College Hospital, London, were studied as controls.

\section{METHODS}

\section{Blood collection}

Five millilitres of blood collected by venepuncture in a final concentration of edetic acid of $10 \mathrm{mmol} / \mathrm{l}$ was immediately separated by centrifugation at $1000 \mathrm{~g}$ at $4^{\circ} \mathrm{C}$ for 15 minutes and the plasma stored at $-70^{\circ} \mathrm{C}$. Another $5 \mathrm{ml}$ of blood was allowed to clot at room temperature for two hours; after centrifugation serum was stored at $-70^{\circ} \mathrm{C}$.

All laboratory investigations were performed by an operator unaware of the clinical data.

\section{C4d and C3d measurement}

C4d levels were determined by a laser nephelometric technique. ${ }^{23}$ Briefly, plasma was brought to $12 \%$ final concentration of polyethylene glycol 6000 and centrifuged at $1500 \mathrm{~g}$ for 30 minutes at $4^{\circ} \mathrm{C}$. This manoeuvre precipitates $\mathrm{C} 4$ and its larger fragments, leaving free $\mathrm{C} 4 \mathrm{~d}$ in the supernatant. The concentration of C4d was then measured by laser nephelometry, using anti-C4 intact antiserum (Behring). C3d plasma levels were measured by a similar technique using anti-C3d antiserum (Dakopatts). ${ }^{25} \mathrm{C} 4 \mathrm{~d}$ and C3d results were expressed as percentages of $a$

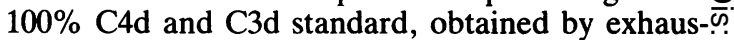
tive activation of complement through the classical $\Rightarrow$ pathway. Serial dilutions of the standard provided $\stackrel{\text { ? }}{7}$ the $\mathrm{C} 4 \mathrm{~d}$ and $\mathrm{C} 3 \mathrm{~d}$ reference curves against which test? samples were read.

\section{C4 and C3 measurement}

Serum concentrations of $\mathrm{C} 4$ and $\mathrm{C} 3$ were deter-ळ mined by laser nephelometry, using specific antisera $\vec{\circ}$ (Behring) in a Behring laser nephelometer, according to the manufacturer's instructions. Results werew expressed in $\mathrm{g} / \mathrm{l}$.

As the initial concentration of intact complementô components may influence the levels of their frag- $-\mathrm{A}$ ments the $\mathrm{C} 4 \mathrm{~d} / \mathrm{C} 4$ and $\mathrm{C} 3 \mathrm{~d} / \mathrm{C} 3$ ratios were calcu- lated, to obtain indices of complement activation $\vec{i}$ independent of the concentration of parent mole $-\frac{\vec{\omega}}{\omega}$ cules. These ratios correlate positively with the ino vivo fractional catabolic rate of $\mathrm{C} 4$ and $\mathrm{C} 3 .{ }^{15} \stackrel{26}{工}$

\section{Statistical analysis}

The mean values of complement indices of patients $\stackrel{\Phi}{\rightrightarrows}$ and controls were compared by the Student's $t$ test. The mean values of the three patient subgroups and of controls were compared using an analysis offo variance (ANOVA) method. This approach atsoo allowed a test for linear trend over the four grous. The ANOVA method is a global significance test, which evaluates whether there is evidence to contra- $-\frac{\partial}{0}$ dict the null hypothesis that all the groups area equivalent. Thus ANOVA represents an extensiond of the $t$ test when the number of groups compared exceeds two. Moreover, within the ANOVA

Table 1 Comparison of complement indices between subgroups of patients and controls

\begin{tabular}{|c|c|c|c|}
\hline & \multicolumn{3}{|c|}{ Analysis of variance (ANOVA) } \\
\hline & $\begin{array}{l}\text { Overall } \\
\text { ANOVA } \\
\left(F_{3}, 74\right)\end{array}$ & $\begin{array}{l}\text { Test for } \\
\text { linear trend } \\
\left(F_{1,74}\right)\end{array}$ & $\begin{array}{l}\text { Departure from } \\
\text { linear trend } \\
\left(F_{2}, 74\right)\end{array}$ \\
\hline C4 & $1.8 \dagger$ & $1 \cdot 1 \dagger$ & $2 \cdot 12 \dagger$ \\
\hline C4d & $29 \cdot 4^{* * *}$ & $86 \cdot 3^{* * *}$ & $0.94 \dagger$ \\
\hline $\mathrm{C} 4 \mathrm{~d} / \mathrm{C} 4$ & $14 \cdot 8^{* * *}$ & $79 \cdot 3^{* * *}$ & $0.01 \dagger$ \\
\hline $\mathrm{C} 3$ & $1.0 \dagger$ & $2 \cdot 3 t$ & $0.43 \dagger$ \\
\hline C3d & $7 \cdot 2^{* * *}$ & $13 \cdot 2^{* *}$ & $3 \cdot 81^{*}$ \\
\hline $\mathrm{C} 3 \mathrm{~d} / \mathrm{C} 3$ & $6 \cdot 8^{* * *}$ & $13 \cdot 2^{* *}$ & $3.66^{*}$ \\
\hline
\end{tabular}

*0.01<p<0.05; ${ }^{* *} 0.001<p<0.01 ;{ }^{* * *} \mathrm{p}<0.001$. †Not significant.

$\mathrm{F}_{3}$, statistic summarises the overall analysis of the oroups. The larger its value, the greater the evidence against the null hypothesis that the group means are equivalent. $F_{1}, 74$ and $F_{2,74}$ statisticses should be considered together in assessing the type of trend (linear or non-linear) across the groups. Low values of both suggest no trend, whereas high values for $F_{1,74}$ and low values for $F_{2,74}$ support a linear trend. 
method it is also possible to test particular subhypotheses - for example, to investigate a linear trend across the groups.

To combat the problem of unequal variances logarithmic transformations of $\mathrm{C} 4 \mathrm{~d}, \mathrm{C} 4 \mathrm{~d} / \mathrm{C} 4, \mathrm{C} 3 \mathrm{~d}$, and $\mathrm{C} 3 \mathrm{~d} / \mathrm{C} 3$ values were used throughout the study. To ascertain whether the difference in the female/ male ratio and in the mean age between patients and controls could affect the results statistical analysis was repeated by considering female subjects only, and with all the subjects divided into groups by age ( $\leqslant 30$ years, $>30$ years).

Statistical computations were performed using the statistical package for the social sciences (SPSS) on the University of London Computer Centre's Amdahl 5980/300.

\section{Results}

Table 1 and Fig. 1 show the results. Indices of
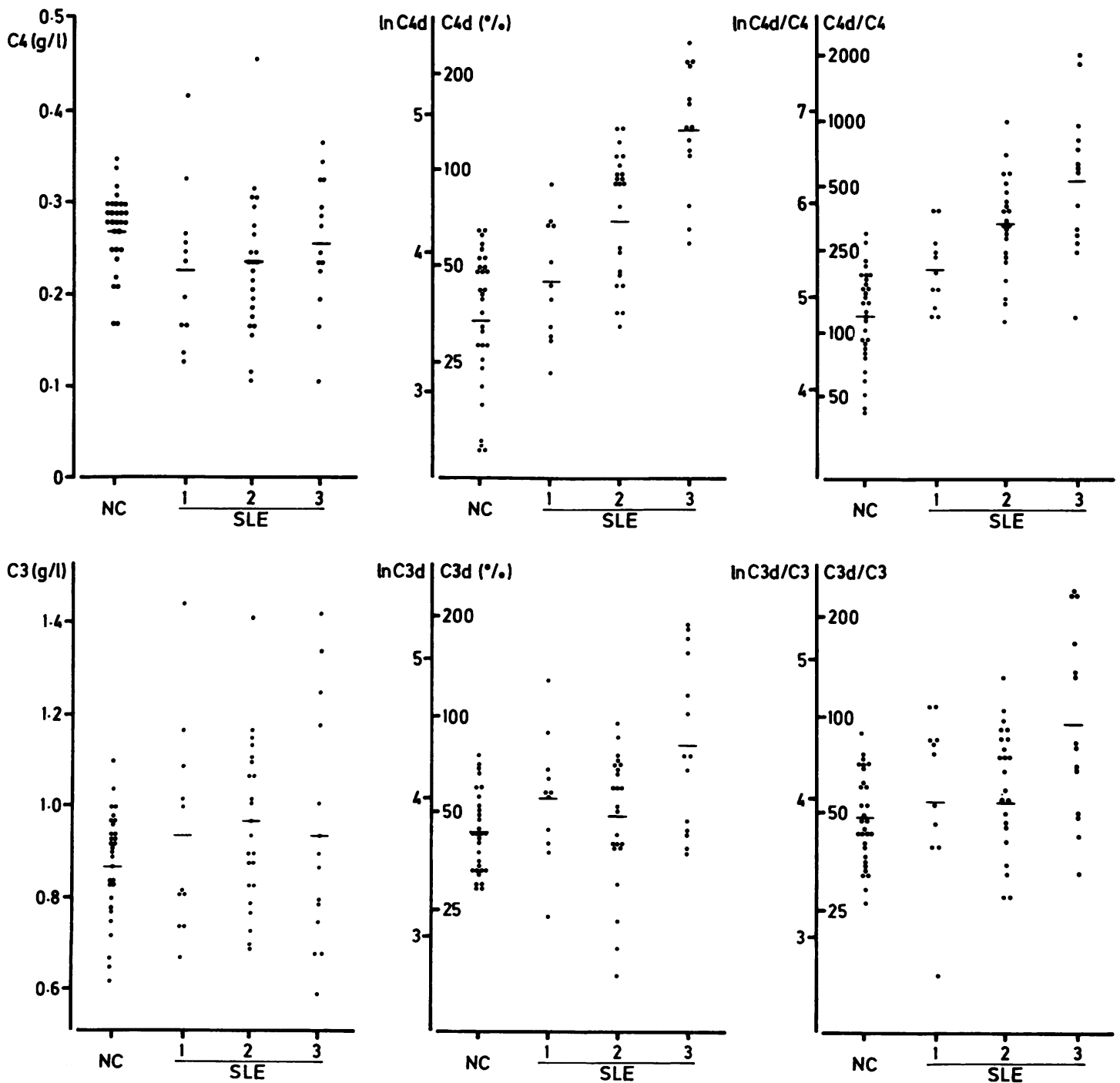

Fig. 1 Complement indices (C4, C4d, C4d/C4,C3,C3d,C3d/C3) in subgroups of patients and controls. Both log transformed (ln) and raw values are given on the vertical axis for $C 4 d, C 4 d / C 4, C 3 d$, and C3d/C3. Horizontal bars represent the mean values. NC=controls; SLE 1, SLE 2, SLE 3=subgroups of lupus patients with increasing grades of disease activity (see text). 
complement activation were significantly higher in patients with SLE than in controls (C4d: $t=6 \cdot 30$, $\mathrm{p}<0.001 ; \mathrm{C} 4 \mathrm{~d} / \mathrm{C} 4: \mathrm{t}=7.14, \mathrm{p}<0.001 ; \mathrm{C} 3 \mathrm{~d}: \mathrm{t}=2.72$, $\mathrm{p}<0.01 ; \mathrm{C} 3 \mathrm{~d} / \mathrm{C} 3: \mathrm{t}=2.47, \mathrm{p}<0.02$ ), and they correlated significantly with disease activity (Table 1). Only the $\mathrm{C} 4$ activation indices $\mathrm{C} 4 \mathrm{~d}$ and $\mathrm{C} 4 \mathrm{~d} / \mathrm{C} 4$ increased in proportion to the grade of disease activity, however-that is, $\mathrm{C} 4 \mathrm{~d}$ and $\mathrm{C} 4 \mathrm{~d} / \mathrm{C} 4$ values were higher in the most active group (group 3) than in group 2 , in group 2 they were higher than in group 1 , and in group 1 they were higher than in controls (Fig. 1). Patients had lower levels of $\mathrm{C} 4$ and higher levels of $\mathrm{C} 3$ than controls $(\mathrm{C} 4: \mathrm{t}=1 \cdot 71, \mathrm{p}<0.05 ; \mathrm{C} 3$ : $\mathrm{t}=2.38, \mathrm{p}<0.01$ ), but no correlation was found between $\mathrm{C} 4$ and $\mathrm{C} 3$ levels and grades of disease activity. Similar results were obtained when data were reanalysed by dividing the subjects either by sex or age. In particular, the linear trends for $\mathrm{C} 4 \mathrm{~d}$ and $\mathrm{C} 4 \mathrm{~d} / \mathrm{C} 4$ were observable for women alone, and for both those aged below and those aged over 30 .

\section{Discussion}

The present study demonstrates the value of measuring activation of the fourth complement component to assess disease activity in systemic lupus erythematosus. This is important as many of the previously described laboratory measurements do not accurately reflect disease activity in SLE.

SLE is considered to be the prototypic human immune complex disease $\mathrm{e}^{27}$ as its clinical manifestations result from the tissue damage caused by formation and deposition of antigen-antibody complexes. ${ }^{5}$ A potential marker of clinical activity should therefore be related to this central pathogenic feature. The measurement of circulating levels of immune complexes, however, does not provide a reliable laboratory index of disease activity, ${ }^{41314}$ possibly because the concentration of immune complexes in serum does not correlate with their levels in tissue, which are of more pathogenic importance.

Because immune complexes incite tissue injury by their ability to activate complement through the classical pathway, and so initiate an inflammatory response ${ }^{21}$ investigations of complement activation should provide an adequate measure of disease activity.

In this study the measure of intact complement factors was found to be of little value in assessing disease activity, in agreement with previous reports. ${ }^{820}$ In our patients levels of $\mathrm{C} 4$ were reduced, but no correlation was found between reduced $\mathrm{C} 4$ levels and degrees of disease activity. This may be owing to the fact that low $\mathrm{C} 4$ levels in SLE can derive from immune consumption and from defective production due to the possession of null allotypes. ${ }^{18}$ In contrast with $\mathrm{C} 4, \mathrm{C} 3$ levels were raised. This increase, which probably results from the behaviour of $\mathrm{C} 3$ as an acute phase reactant, ${ }^{17} \overrightarrow{\overrightarrow{\vec{D}}}$ was neither correlated with the grade of disease $\stackrel{\rho}{\rightarrow}$ activity nor able to differentiate between subgroups of patients with different degrees of clinical severity. $\frac{\bar{F}}{\bar{C}}$

A correlation between disease activity and com- $\frac{\vec{\sigma}}{\vec{\sigma}}$ plement activation was found by measuring indices $\varrho$ of $\mathrm{C} 3$ cleavage, with $\mathrm{C} 3 \mathrm{~d}$ and $\mathrm{C} 3 \mathrm{~d} / \mathrm{C} 3$ increasing $\%$ with the grades of disease activity. When the $\vec{\circ}$ patients were stratified in subgroups according to their clinical condition, however, the $\mathrm{C} 3$ indices of $\vec{\omega}$ activation failed to discriminate between groups, in agreement with a previous report. ${ }^{20}$ This could be due to the fact that the cleavage of $\mathrm{C} 3$ is a relatively late event in the sequence of the classical comple- $-\rightarrow$ ment pathway, is influenced by activation of the $\overrightarrow{0}$ alternative pathway, ${ }^{22}$ and is affected by the action $\vec{\omega}$ of plasma proteases ${ }^{28}$ and inhibitors. ${ }^{29}$

Cleavage of $\mathrm{C} 4$ represents an early event in the $\stackrel{\circ}{\sim}$ activation of the classical complement pathway, $\vec{z}$ immediately following immune complex mediated C1qrs conversion. ${ }^{22}$ Thus it is not surprising that $\frac{\Phi}{3}$ indices of $\mathrm{C} 4$ cleavage provide the best measure of disease activity in SLE, as shown in this study. C4d and $\mathrm{C} 4 \mathrm{~d} / \mathrm{C} 4$ increase proportionally with the $\overrightarrow{0}$ increasing grades of disease activity and, moke importantly, allow a clear distinction between exshi subgroup of patients and all the others with different? severity of the disease. Our results compare favourably with those recently reported by Falk andळ colleagues, ${ }^{30}$ who found that the levels of comple- $\frac{}{\mathbb{D}}$ ment attack complex, a measure of complement activation, exceeded the highest normal value in eight of 14 patients with active disease. In our study the levels of $C 4 \mathrm{~d}$ fragment exceeded the highest control value in 12 of 14 patients with a similar clinical state.

Our data indicate that the indices of activation of the fourth complement component provide a sensitive measurement of disease activity in SLE. This $\delta$ should prove useful in the management of lupus patients.

We are indebted to Dr D Lowe for statistical assistance and advice. Dr G Senaldi is supported by Fondazione Anna Villa Rusconi, Varese, Italy.

\section{References}

1 Morrow W J W, Isenberg D A. Autoimmune rheumatic disease. Oxford: Blackwell Scientific, 1987.

2 Fries J F, Holman H R. Systemic lupus erythematosus, a clinical analysis. In: Smith L H, ed. Major problems in internaf( medicine. Vol 6. Philadelphia: Saunders, 1975.

3 Morrow W J W, Isenberg D A, Parry H F, Snaith M L: C-reactive protein in sera from patients with systemic lupus? erythematosus. J Rheumatol 1981; 8: 599-604.

4 Morrow W J W, Isenberg D A, Todd-Pokropek A, Parry H F 
Snaith M L. Useful laboratory measurements in the management of systemic lupus erythematosus. $Q J$ Med 1982; 51: 125-38.

5 Zvaifler N J, Woods V L. Etiology and pathogenesis of systemic lupus erythematosus. In: Kelley W N, Harris E D Jr, Ruddy S, Sledge C B, eds. Textbook of rheumatology. 2nd ed. Philadelphia: Saunders, 1985: 1042-70.

6 Lloyd W, Shur P H. Immune complexes, complement, and antiDNA in exacerbations of systemic lupus erythematosus (SLE). Medicine (Baltimore) 1981; 60: 208-17.

7 Isenberg D A, Shoenfeld Y, Schwartz R S. Multiple serological reactions and their relationship to clinical activity in systemic lupus erythematosus. Arthritis Rheum 1984; 27: 132-8.

8 Isenberg D A, Colaco C B, Dudeney C, Todd-Pokropek A, Snaith M L. The relationship of anti-DNA antibody idiotypes and anti-cardiolipin antibodies to disease activity in systemic lupus erythematosus. Medicine (Baltimore) 1986; 65: 46-55.

9 Ludvico C L, Zweiman B, Myers A R, Herbert J, Green P A. Predictive value of anti-DNA antibody and selective laboratory studies in systemic lupus erythematosus. J Rheumatol 1980; 7: 843-9.

10 Adler M K, Baumgarten A, Hecht B, Siegel N J. Prognostic significance of DNA binding capacity patterns in patients with lupus nephritis. Ann Rheum Dis 1975; 34: 444-50.

11 Hecht B, Siegel N, Adler M, Kashigarian M, Hayslett J P. Prognostic indices in lupus nephritis. Medicine (Baltimore) 1976; 55: 163-81.

12 Levinsky R J, Cameron J S, Soothill J F. Serum immune complexes and disease activity in lupus nephritis. Lancet 1977; i: 564-7.

13 Inman R D, Fong J K K, Pussell B A, Ryan P J, Hughes G R V. The $\mathrm{Clq}$ binding assay in systemic lupus erythematosus: discordance with disease activity. Arthritis Rheum 1980; 23: $1282-6$.

14 Valentijn R M, Van Overhagen $\mathrm{H}$, Hazeovoet $\mathrm{H}$ M, et al. The value of complement and immune complex determinations in monitoring disease activity in patients with systemic lupus erythematosus. Arthritis Rheum 1985; 28: 904-13.

15 Swaak A J G, Van Rooyen A, Vogelaar C, Pillay M, Hack E. Complement (C3) metabolism in systemic lupus erythematosus in relation to the disease course. Rheumatol Int 1986; 6: 221-6.

16 Shur P H. Complement and lupus erythematosus. Arthritis Rheum 1982; 25: 793-8.

17 Schutte M, Dicamelli R, Murphy P, et al. Effects of anesthesia, surgery and inflammation upon host defence mechanisms. I. Effects upon the complement system. Int Arch Allergy Appl Immunol 1975; 48: 706-20.
18 Fielder A H L, Walport M J, Batchelor J R, et al. Family study of the major histocompatibility complex in patients with systemic lupus erythematosus: importance of null alleles of C4A and C4B in determining disease susceptibility. $\mathrm{Br}$ Med $J$ 1983; 286: $425-8$.

19 Cooper N R, Nemerow G R, Meyers J T. Methods to detect and quantitate complement activation. Seminars in Immunopathology 1983; 6: 173-94.

20 Morrow W J W, Williams D J P, Ferec C, et al. The use of C3d as a means of monitoring clinical activity in systemic lupus erythematosus and rheumatoid arthritis. Ann Rheum Dis 1983: 42: $668-71$

21 Dixon F J. Mechanisms of immunologic injury. In: Good R A. Fisher D W, eds. Immunobiology. Stamford: Sinauer Associates, 1971: 161-6.

22 Cooper N R. The complement system. In: Stites D P, Stobo J D, Wells V J, eds. Basic and clinical immunology. 6th ed. East Norwalk: Appleton and Lange, 1987: 114-27.

23 Davies E T, Nasaruddin B A, Alhaq A, Senaldi G, Vergani D. Clinical application of a new technique measuring $\mathrm{C} 4 \mathrm{~d}$ for the assessment of activation of the classical complement pathway. $J$ Clin Pathol 1988; 41: 143-7.

24 Tan E M, Cohen A S, Fries J F, et al. The 1982 revised criteria for the classification of systemic lupus erythematosus. Arthritis Rheum 1982; 25: 1271-7.

25 Vergani D, Bevis L, Nasaruddin B A, Mieli-Vergani G, Tee D E H. Clinical application of a new laser nephelometric technique to measure complement activation. J Clin Pathol 1983; 36: 793-9.

26 Milgrom H, Curd J G, Kaplan R A, Muller-Eberard H J, Vaughan $\mathrm{J}$ H. Activation of the fourth component of complement (C4): assessment by rocket immunoelectrophoresis and correlation with the metabolism of C4. J Immunol 1980; 124: 2780-5.

27 Koffler D, Agnello V, Thoburn R, Kunkel H G. Systemic lupus erythematosus: prototype of immune complex nephritis in man. J Exp Med 1971; 134 (suppl): 169-79.

28 Sundsmo J S, Fair D S. Relationship among the complement, kinin, coagulation and fibrinolytic systems. Seminars in Immunopathology 1983; 6: 231-58.

29 Medicus R G, Melamed J, Arnaout M A. The role of human factor I and C3b receptor in the cleavage of surface-bound C3bi molecules. Eur J Immunol 1983; 13: 465-70.

30 Falk R J, Dalmasso A P, Younki K, Lam S, Michael A. Radioimmunoassay of the attack complex of complement in serum from patients with systemic lupus erythematosus. $N$ Engl J Med 1985; 312: 1594-9. 